
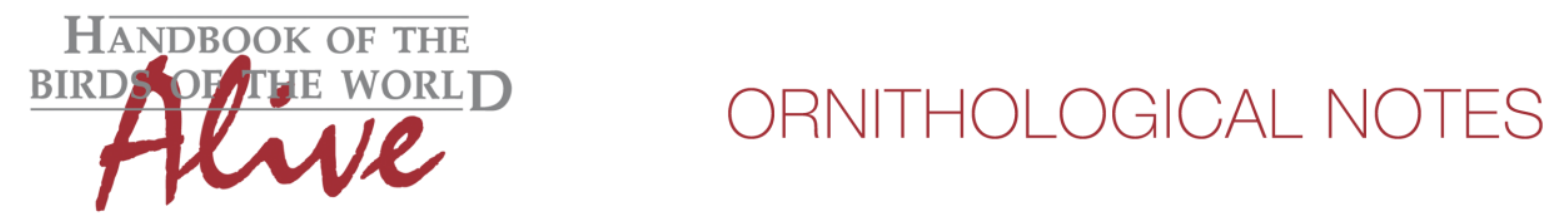

\title{
Notes on the vocalizations of Palm Crow (Corvus palmarum)
}

\section{Peter Boesman}

In the following we briefly analyze and compare voice of the two races of Palm Crow (Corvus palmarum). We also try to quantify the extent of any vocal differences using the criteria proposed by Tobias et al. (2010), as a support for taxonomic review. We have made use of sound recordings available on-line from Xeno Canto (XC).

Most common vocalization of both races is a loud nasal somewhat drawn-out "caaah" (palmarum) or crrah" (minutus) (Fig. 1).

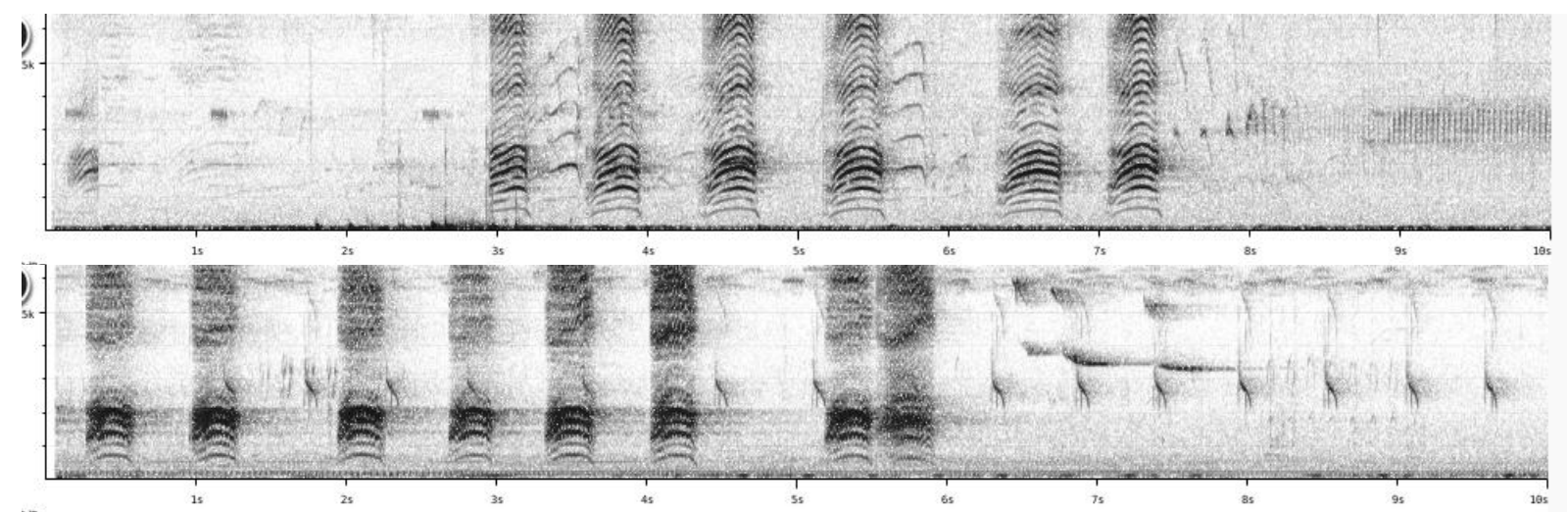

Figure 1: typical call of race minutus (top) and race palmarum (bottom)

Despite looking quite similar on a sonogram, they are readily distinguished by ear: palmarum has a distinct vibrating voice while minutus hasn't (based on all available XC recordings). By zooming in on the sonogram (more detailed time scale), this difference becomes indeed apparent (Fig. 2). Given that variability in 'Crow language' is not spectacular, this may well be an important distinguishing feature.

A further possible feature is that minutus seems to call more with 'drawn-out notes' (of which max. pitch lies in the second half of the note) compared to palmarum (which has more symmetrically shaped notes), but here there is at least some overlap, and more recordings would be needed to confirm this statistically.

At present, the main vocal difference clearly is the vibrating voice of palmarum. Quantification is possible by expressing the number of oscillations per note and would lead to a vocal score of about 3. 

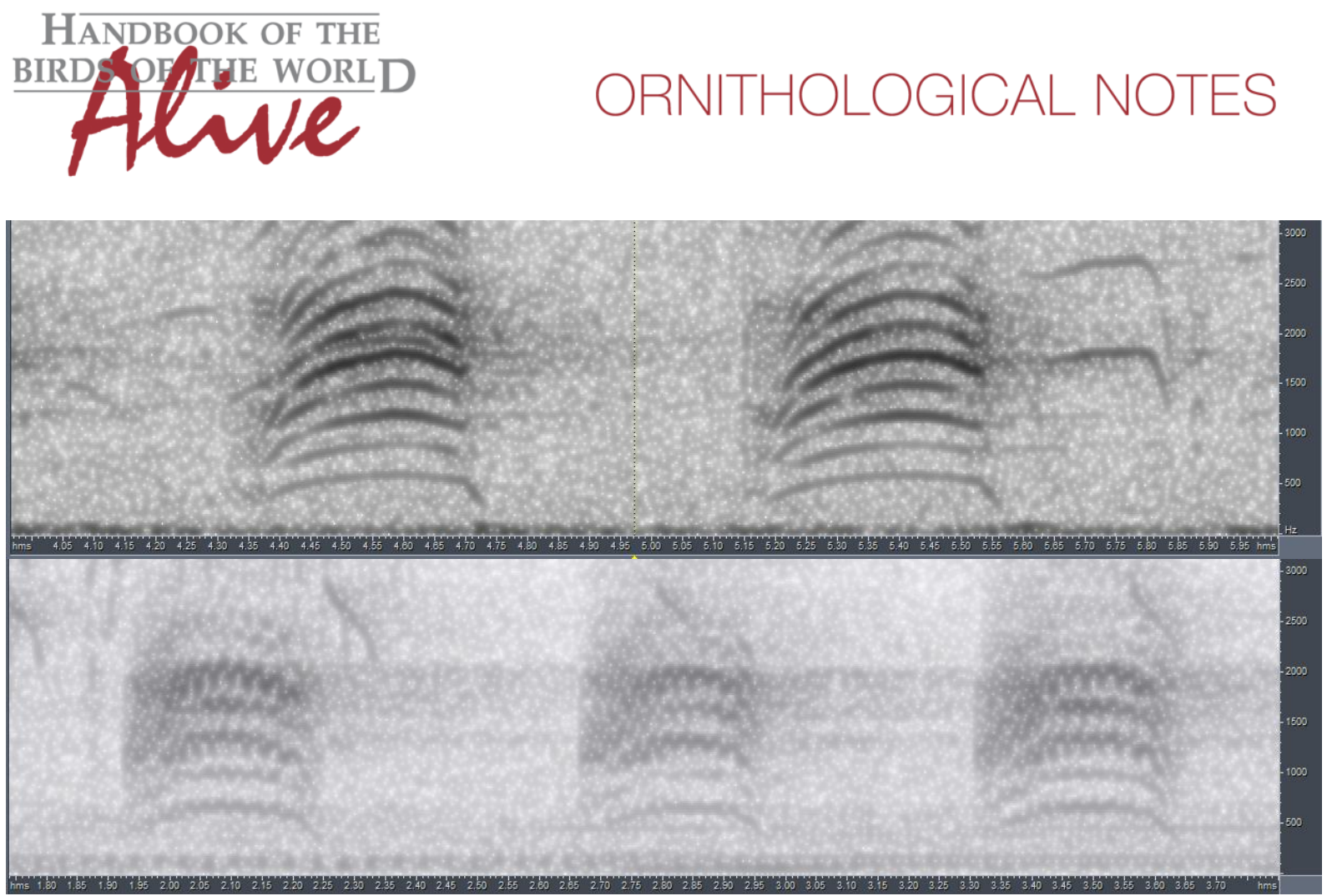

Figure 2: typical call of race minutus (top) and race palmarum (bottom) on a more detailed time scale

This note was finalized on 27th January 2016, using sound recordings available on-line at that moment. We would like to thank in particular the sound recordists who placed their recordings for this species on XC: Lance Benner, Brian Cox, Ian Davies, Laura Gooch, Jon King, Hans Matheve and Andy Mitchell.

\section{References}

Tobias, J.A., Seddon, N., Spottiswoode, C.N., Pilgrim, J.D., Fishpool, L.D.C. \& Collar, N.J. (2010). Quantitative criteria for species delimitation. Ibis 152(4): 724-746.

\section{Recommended citation}

Boesman, P. (2016). Notes on the vocalizations of Palm Crow (Corvus palmarum). HBW Alive Ornithological Note 209. In: Handbook of the Birds of the World Alive. Lynx Edicions, Barcelona. (retrieved from http://www.hbw.com/node/932158 on 2 September 2016). 